\title{
Seabird foraging tactics and water clarity: are plunge divers really in the clear?
}

\author{
J. Christopher Haney ${ }^{1}$, Amy E. Stone ${ }^{2}$ \\ ${ }^{1}$ Alaska Fish and Wildlife Research Center, US Fish and Wildlife Service, 1011 E. Tudor Rd, Anchorage, Alaska 99503, USA \\ ${ }^{2}$ Institute of Marine Science, University of Alaska, Fairbanks, Alaska 99775, USA
}

\begin{abstract}
A steep turbidity gradient across 3 shelf water masses and the Gulf Stream on the upper continental slope off the coast of the southeastern USA formed the basis for testing relationships between predator foraging tactics and relative detectability of prey. Censuses of seabirds were used to test a hypothesis originally proposed by Ainley (1977): plunge diving (plummeting from the air to subsequently capture prey underwater using the momentum of the fally is more prevalent in clear as opposed to turbid surface waters. Twelve species of seabirds regularly used plunge diving to obtain prey in the study area: the tropicbirds Phaethon lepturus and P. aethereus, the boobies and gannet Sula dactylatra, S. leucogaster, and S. bassanus, respectively, and the terns Sterna maxima, S. sandvicensis, $S$. hirundo, S. paradisaea, S. forsteri, and S. antillarum. Only P. lepturus was significantly more common in clear water. Five plunge-diving species were significantly more common in turbid waters. Neither the total number nor the proportion of plunge-diving bird species within the assemblage increased over more transparent waters. Significant decreases in the total number of plunge-diving individuals, and in the proportions of individuals within the assemblage using plunge diving, occurred over waters with increasing transparency. Because the latter findings are directly counter to predictions arising from Ainley's hypothesis, we conclude that water clarity has yet to be clearly implicated as an influence on the allocation of foraging tactics in aerial seabirds.
\end{abstract}

\section{INTRODUCTION}

Successful foraging by predators is contingent on detectability as well as abundance of their prey. Because visually-oriented aquatic predators depend upon light to locate prey, capture success should be closely related to water clarity. Fish predators selectively remove large-bodied forms (Brooks \& Dodson 1965, Galbraith 1967, Lynch 1979) and reductions in the reactive distances of planktivorous fish occur in turbid water (Vinyard \& O'Brien 1976, Confer et al. 1978, Gardner 1981). Turbid water may offer protection to prey, with species composition and body sizes changing across turbidity/clarity gradients (Timms 1970, McCabe \& O’Brien 1983, Geddes 1984, Patalas \& Salki 1984). Effects of water clarity on the structure of aquatic communities are not always easily interpreted, however (Zettler \& Carter 1986). For example, reduced predation pressure from fish on zooplankton caused by natural declines in fish abundance or by removal may result in rather than from differences in water transparency (Andersson et al. 1978, Henrickson et al. 1980 . Eriksson 1985).
Bird predators in freshwater (Eriksson 1985) and marine habitats (Ainley 1977) are also thought to be affected by water clarity. At tropical latitudes in the eastern Pacific Ocean, Ainley (1977) found that species diving from the air to capture prey at or slightly below the surface (plunge divers) were more common in transparent than in turbid waters. Species foraging by diving from the ocean surface to capture prey underwater (pursuit divers) were significantly correlated with waters of increasing turbidity. Ainley hypothesized that clear water is an advantage to birds plunging from the air because birds continually adjust their position and rate of descent to match the location of visually-located prey. On the other hand, he suggested that seabirds swimming underwater are less likely to surprise their prey in transparent water. For pursuit divers, turbid water may permit closer approach prior to capture, in a manner similar to sitand-wait strategies used by concealed or camouflaged predators.

Several authors have pointed out that individual species of seabirds do not always conform to Ainley's (1977) original prediction that plunge diving is more 
prevalent in clear than in turbid waters (Ainley \& Boekelheide 1983, Hunt \& Schneider 1987). Peruvian boobies Sula variegata plunge dive regularly in turbid waters of the Peruvian Current as do northern gannets Sula bassana in the Atlantic Ocean. Terns also dive from the air into less transparent coastal waters on the continental shelves of several ocean basins. But Ainley's hypothesis was not directed at predictions for single species, but rather toward seabird species groupings. We are not aware of any attempt to test this hypothesis using seabird assemblages from other regions and water masses.

Here we test the hypothesis that seabird foraging tactics are influenced by a turbidity gradient in surface waters of the continental shelf and Gulf Stream off the coast of the southeastern United States. Because of possible spurious correlations between pursuit divers and water clarity in this region due to water depth (see 'Discussion'), we dealt primarily with the relationships of plunge diving species to the turbidity gradient. For Ainley's hypothesis to hold true, we expected one or both of the following situations to hold true: (1) the absolute number of plunge-diving species or individuals should increase significantly over more transparent waters, or (2) the relative percentage of plunge-diving species or individuals within the assemblage should increase over transparent water masses.

\section{STUDY AREA}

Studies of oceanographic properties off the coast of the southeastern United States indicate that the continental shelf can be separated into 3 depth zones, each corresponding to a water mass having a characteristic circulation and exchange regime (Atkinson et al. 1983). The outer shelf ( 41 to $200 \mathrm{~m}$ isobaths) is dominated by transient, northward-propagating events (meanders, eddies, and intrusions) at $2 \mathrm{~d}$ to $2 \mathrm{wk}$ intervals (Lee \& Atkinson 1983). Middle shelf (21 to $40 \mathrm{~m}$ isobaths) waters are influenced by wind, the Gulf Stream, and density forcing. The inner shelf (0 to $20 \mathrm{~m}$ isobaths) is strongly influenced by atmospheric forcing and river run-off.

A turbidity gradient exists across the 3 shelf water masses and the adjacent Gulf Stream which overlies the upper continental slope (201 to $800 \mathrm{~m}$ isobaths). In general, the turbidity gradient is marked by abrupt changes in water clarity and color at or near the frontal boundaries between water masses, especially between inner and middle shelf water, and between outer shelf and Gulf Stream water. The turbidity gradient between middle and outer shelf water is more gradual. As color fronts are perceived to lie where the depth-integrated light undergoes a distinct spectral shift in the region of rapidly descending isopycnals, the turbidity fronts may not correspond exactly (at scales of a few meters or tens of meters) to the surface manifestation of steepest pycnoclinal change (cf. Bowman \& Iverson 1977). Abrupt changes in turbidity may also occur independently of the pycnoclinal gradient where sediment from river discharge falls out of suspension.

Cross-shelf positions of the turbidity fronts vary 10 to $20 \mathrm{~km}$ about a mean corresponding to a depth contour or distance from land (e.g. Olson et al. 1983). Absolute values of water clarity vary seasonally as the rate of river discharge changes (Blanton \& Atkinson 1983), or as upwelling and subsequent growth of phytoplankton populations influence water clarity (Yoder et al. 1983). At all seasons, however, the structure and orientation of the turbidity gradient persists, with the inner shelf waters being most turbid and the outer shelf and Gulf Stream waters most transparent.

\section{MATERIALS AND METHODS}

Four types of measurements were used to characterize the turbidity gradient in the study area. The color of seawater was recorded with the numbered Forel-Ule color scale (Sverdrup et al. 1942) using the white background of a Secchi disk. Waters with high clarity measure blue, and waters of increasing turbidity measure green to yellow with this method. A Secchi disk was also employed to measure relative clarity among the 4 water masses (deeper depths corresponding to higher clarity; Preisendorfer 1986). Water color and Secchi depth were both measured between 2 and 11 May 1985 from the RV 'Oregon II'. An illuminance meter was used to calculate depth-integrated transmission (in $\mu$ Einstein $\mathrm{m}^{-2} \mathrm{~s}^{-1}$ ) and the vertical attenuation (extinction coefficient, $k$ ) of light in the water masses. High values for light transmission and low values for vertical attenuation indicated high water clarity. The latter 2 calculations were made during the GABEX (Georgia Bight Experiment) cruises aboard the RV 'Iselin' in April 1980. When more than one station measured water clarity within a water mass (Fig. 1, Appendix 1), mean values of the clarity index were computed.

Seabirds were censused during 49 ship-board cruises between May 1982 and June 1985. Birds were counted in an instantaneously-changing, $90^{\circ}$ sector transect with radius $300 \mathrm{~m}$ during $15 \mathrm{~min}$ periods (Haney 1986). Counts were generally conducted normal to the coastline and isobaths, but parallel to the turbidity gradient. Most censusing occurred between $29^{\circ}$ and $32^{\circ} \mathrm{N}$ latitude. Counts were stratified by shelf and slope domains (Table 1) that were identical to those used in defining the turbidity gradient.

Numbers of species and individuals using plunge- 
Fig. 1. Station sites on the southeastern USA inner shelf (IS), middle shelf (MS), outer shelf (OS), and upper slope (US) where water clarity indices were measured. Dotted line: mean position of the western Gulf Stream frontal boundary

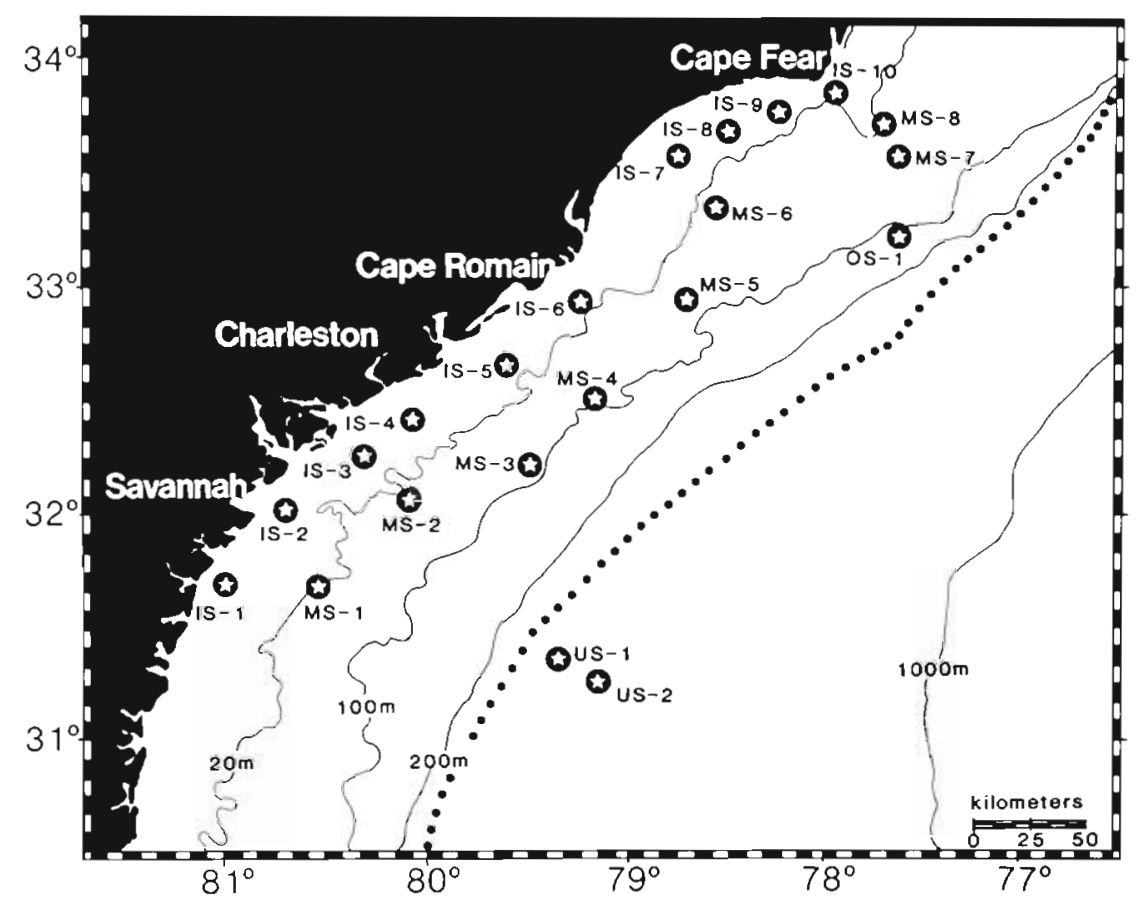

Table. 1 Seabird count effort on the southeastern United States continental shelf and slope stratified by bathymetry

\begin{tabular}{lllll|}
\hline & $\begin{array}{c}\text { Inner } \\
\text { shelf }\end{array}$ & $\begin{array}{c}\text { Middle } \\
\text { shelf }\end{array}$ & $\begin{array}{c}\text { Outer } \\
\text { shelf }\end{array}$ & $\begin{array}{c}\text { Upper } \\
\text { slope }\end{array}$ \\
\hline No. of 15 min counts & 364 & 548 & 634 & 572 \\
$\begin{array}{l}\text { Surface area censused } \\
\left(\mathrm{km}^{2}\right)\end{array}$ & 458 & 661 & 669 & 688 \\
a Inner shelf: $0-200 \mathrm{~m}$ depth; middle shelf: $21-40 \mathrm{~m}$; outer \\
shelf: $41-200 \mathrm{~m}$; upper slope: 201-800 m \\
\hline
\end{tabular}

diving or pursuit-diving foraging tactics (Ashmole 1971, Ainley 1977; Appendix 2) were determined for each water mass. Proportions of seabird species and individuals using plunge diving within the assemblage were also compared to water clarity, because absolute numbers of seabirds among water masses may have varied for reasons unrelated to water clarity per se (e.g. productivity/standing stocks of prey). We categorized species as plunge divers if they plummetted from the air and used the momentum of the fall to catch prey. We included species that submerged partially as well as fully during the plunge. Species were listed as pursuit divers if they submerged from a position on the ocean surface to pursue and capture prey underwater using wings or feet for propulsion. Categorizations of foraging strategies were made on a species-by-species basis because differences in strategies occurred within families and genera. For example, bridled (Sterna anaethetus) and sooty terns (S. fuscata) did not plunge dive, but the remaining tern species in the study area did.

Spearman's rank correlation coefficient $\left(r_{\mathrm{s}}\right)$ tested for relations between the ranks of plunge-diving foraging tactics and ranks of water clarity among water masses. Pearson product moment correlation $(r)$ was used to test for relations among the water clarity indices, and as an additional test for determining trends in individual species abundances and water clarity. Because small sample sizes and few degrees of freedom in the tests increased the risk of Type II error, the statistical null hypotheses were rejected at $p<0.10$.

\section{RESULTS}

All 4 clarity indices were significantly intercorrelated (Table 2). Each comparison explained 91 to $98 \%$ of the variance between indices. Therefore the indices were used interchangeably to describe the turbidity gradient. Negative correlations indicated inverse relations between the values of clarity indices (Fig. 2). For example, as light transmission and vertical attenuation increased across the shelf, Secchi depth decreased. At any given depth, considerably more light was transmitted in outer shelf and Gulf Stream waters than in inner and middle shelf water (Fig. 3).

The numbers of both plunge divers and pursuit divers decreased with increasing water transparency (Table 3, Fig. 2). Before statistical hypothesis tests 
Table 2. Correlation $(x)$ matrix of water clarity indices measured in 4 continental shelf and slope water masses. Light transmission values were based on the amount of light (expressed in $\mu$ Einstein $\mathrm{m}^{-2} \mathrm{~s}^{-1}$ ) at $10 \mathrm{~m}$ depth. Vertical attenuation values used were based on the extinction coefficient of light, $k$

\begin{tabular}{|lccc|}
\hline Variable & $\begin{array}{c}\text { Light } \\
\text { transmission }\end{array}$ & $\begin{array}{c}\text { Vertical } \\
\text { attenuation }\end{array}$ & $\begin{array}{r}\text { Water } \\
\text { color }\end{array}$ \\
\hline Vertical attenuation & $-0.990^{\circ} \cdot{ }^{\circ}$ & & \\
Water color & $-0.956^{\circ}$ & $0.973^{\circ}$ & \\
Secchi depth & $0.958^{\circ}$ & $-0.987^{\circ}$ & $-0.962^{\circ}$ \\
& & & \\
a Significance levels: & ${ }^{\circ} p<0.05^{\circ}, \cdots p<0.01 ;$ df $=2$ \\
\hline
\end{tabular}

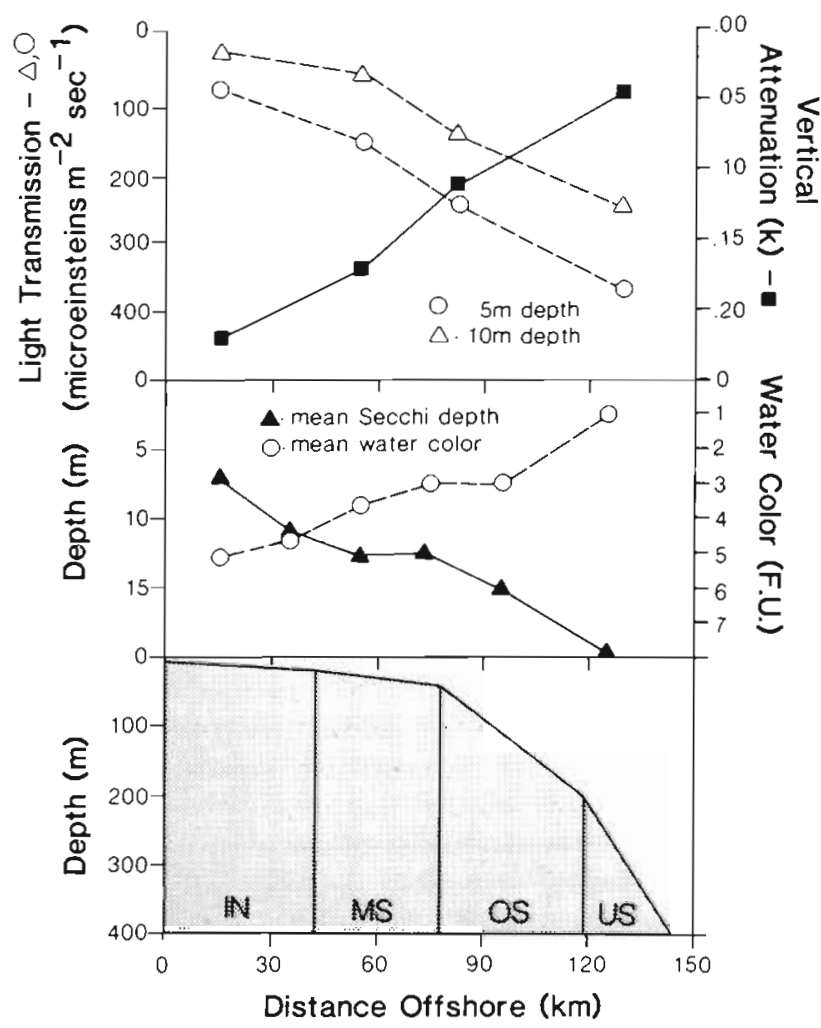

Fig. 2. Gradients in water clarity versus shelf depth and distance offshore. (Abbreviations for shelf and slope domains are given in Fig. 1 legend)

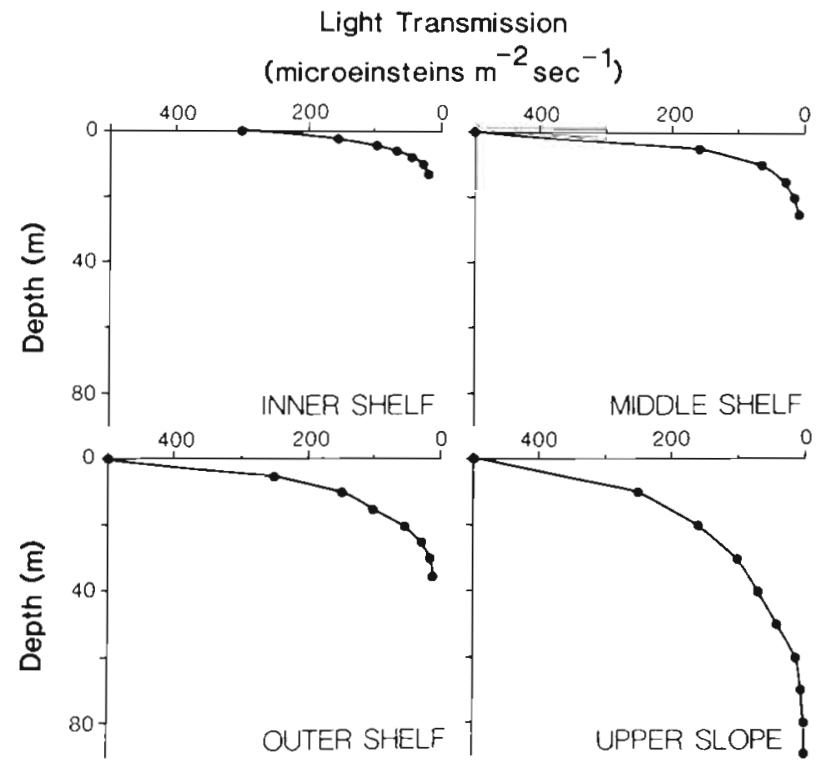

Fig. 3. Light attenuation with depth in 4 continental shelf and slope water masses off the southeastern USA.

between clarity indices and bird abundances were conducted, the absolute numbers were adjusted for effort (Table 1) and expressed as numbers of birds $\mathrm{km}^{-2}$. Of 12 plunge-diving species occurring in the study area only one, the white-tailed tropicbird Phaethon lepturus, was significantly more common in clear water (Table 4). The northern gannet Sula bassana, royal tern Sterna maxima, sandwich tern S. sandvicensis, common tern $S$. hirundo, and least tern $S$. antillarum were all significantly more common in turbid water.

Neither numbers nor proportions of plunge-diving species increased significantly over transparent waters defined by Secchi depth (Fig. $4 ; r_{\mathrm{S}}=-0.32,+0.40$, respectively; $p>0.10$ ). Numbers and proportions of individual birds within the assemblage that used plunge-diving foraging tactics decreased significantly across the turbidity gradient (Fig. $5 ; I_{5}=+1.00,+1.00$, respectively; $p<0.10$ ). Thus, the distributions of plunge-diving foraging tactics did not conform to predictions derived from Ainley's (1977) hypothesis.

Table 3. Numbers of seabird species and individuals in 4 water masses having different water clarity (Figs, 2 and 3) categorized by foraging behavior

\begin{tabular}{lcrrr|}
\hline & Inner shelf & Middle shelf & Outer shelf & Upper slope \\
\hline Total no. of species & 37 & 30 & 31 & 25 \\
No. of plunge-diving species & 8 & 8 & 10 & 6 \\
No. of pursuit-diving species & 10 & 3 & 1 & 1 \\
Total no. of individuals & 3772 & 2662 & 50 & 1910 \\
No. of plunge-diving individuals & 1340 & 862 & 10 & 0 \\
No. of pursuit-diving individuals & 566 & & 50 \\
\hline
\end{tabular}


Table 4. Relative abundances and correlations of individual plunge-diving seabird species with 4 water masses having different clarity (Secchi depth). Positive correlations indicate greater abundance over more transparent water

\begin{tabular}{|c|c|c|c|c|c|c|}
\hline \multirow[t]{2}{*}{ Species } & \multicolumn{4}{|c|}{ Density (birds $\mathrm{km}^{-2}$ ) per water mass } & \multicolumn{2}{|c|}{ Correlation ${ }^{b}$} \\
\hline & Inner shelf & Middle shelf & Outer shelf & Upper shelf & $r$ & $r_{5}$ \\
\hline Phaethon lepturus & 0.00 & $0.00^{\mathrm{a}}$ & $0.00^{\mathrm{a}}$ & 0.01 & $0.970 \cdots$ & $1.000^{\circ}$ \\
\hline Phaethon aethereus & 0.00 & 0.00 & $0.00^{\mathrm{a}}$ & 0.00 & 0.202 & 0.258 \\
\hline Sula dactylatra & 0.00 & $0.00^{\circ}$ & $0.00^{\mathrm{d}}$ & $0.00^{a}$ & 0.826 & 0.800 \\
\hline Sula leucogaster & 0.00 & 0.00 & $0.00^{\circ}$ & 0.00 & 0.202 & 0.258 \\
\hline Sula bassanus & 0.68 & 0.17 & 0.02 & 0.00 & $-0.916^{\circ}$ & $-1.00^{\circ}$ \\
\hline Pelecanus occidentalis & 0.11 & 0.00 & 0.00 & 0.00 & -0.383 & -0.775 \\
\hline Sterna maxima & 0.97 & 0.02 & $0.00^{\mathrm{a}}$ & $0.00^{\mathrm{a}}$ & -0.833 & $-1.000^{\circ}$ \\
\hline Sterna sandvicensis & 0.15 & $0.00^{\mathrm{a}}$ & $0.00^{\mathrm{a}}$ & 0.00 & $-0.913^{\circ}$ & $-1.000^{\circ}$ \\
\hline Sterna hirundo & 0.81 & 0.64 & 0.02 & 0.02 & $-0.900^{\circ}$ & $-1.000^{\circ}$ \\
\hline Sterna paradisaea & $0.00^{\mathrm{a}}$ & 0.00 & 0.01 & 0.01 & -0.721 & 0.60 \\
\hline Sterna forsteri & 0.17 & $0.00^{\mathrm{a}}$ & 0.00 & 0.00 & -0.837 & -0.949 \\
\hline Sterna antillarum & 0.03 & $0.00^{\mathrm{a}}$ & $0.00^{\mathrm{a}}$ & $0.00^{\alpha}$ & -0.848 & $-1.000^{\circ}$ \\
\hline
\end{tabular}
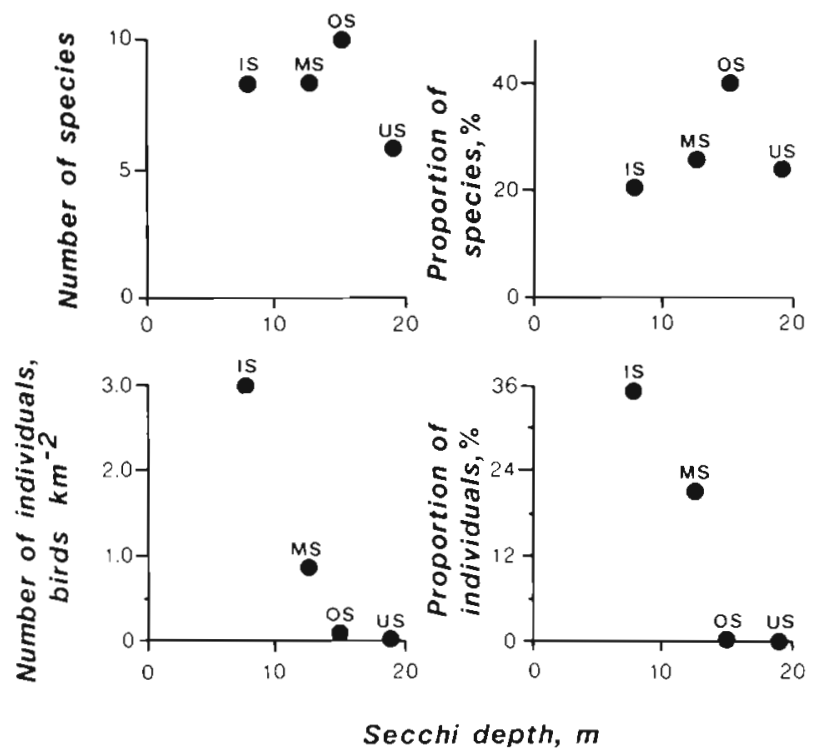

Fig. 4. Correlations of numbers and proportions of plungediving species and individuals plotted versus water clarity (measured by Secchi depth). (Abbreviations for data points are given in Fig. 1 legend)

\section{DISCUSSION}

Distributions of pursuit-diving seabirds in our study did not constitute a good test of Ainley's hypothesis for the influence of water clarity on predator foraging tactics. Even if prey are less abundant in waters of greater transparency, pursuit divers may be able to compensate (Eriksson 1985). Compensation may come about either through increased diving depth, or through greater detectability of prey in clear water. On the continental shelf of the southeastern USA, increasing water transparency is correlated with water depth (Fig. 2). Since many pursuit divers in the study area (Appendix 2) feed on benthic as well as demersal prey, reductions in the cross-shelf abundances of some species may have arisen because such prey were below their maximum diving depths and thus inaccessible further offshore. A better test for surface divers would be made by examining distributions over an alongshelf (i.e. equal-depth) turbidity gradient.

The compounding influence of water depth does not apply to seabirds that plunge dive, however. Some
Fig. 5. (A) Proportion of species, (B) proportion of individuals, and $(C)$ relative abundances of plunge-diving seabirds within seabird assemblages in 4 water masses. (Abbreviations for water masses are given in Fig. 1 legend.) Clarity index here, $k$, is the vertical attenuation coefficient. Water clarity increases from left to right
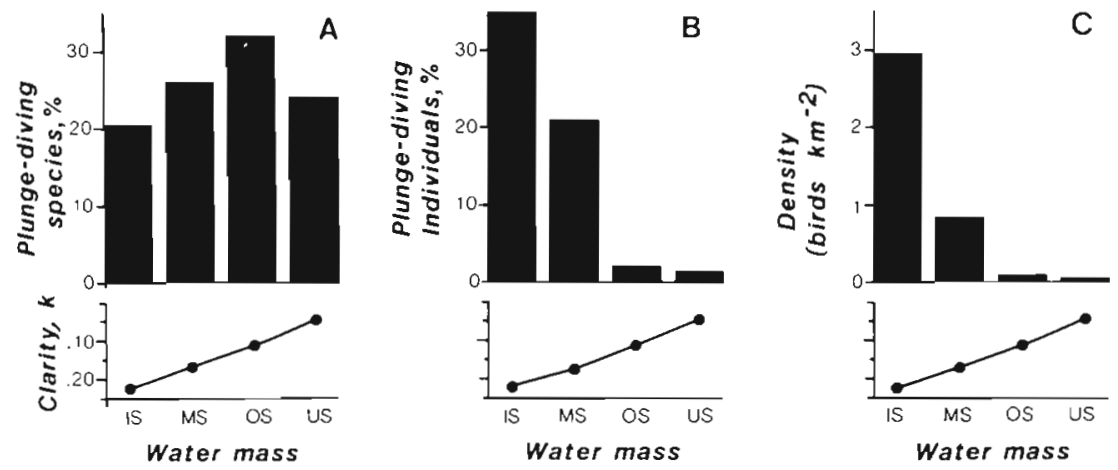
terns do not dive below $1 \mathrm{~m}$ (Salt \& Villard 1971) and even large heavy species such as gannets remain in the upper $2 \mathrm{~m}$ of the water column during most dives (pers. obs.). Changes in the clarity of surface waters would thus seem likely to exert more influence on rates of prey encounter for this group of seabird predators. However, we found no evidence that plunge divers were more common in transparent water. These results are consistent with the predictions of Eriksson (1985), who argued on geometric grounds that changes in water clarity should have little effect on the ability of plunge divers to detect prey.

Differences between our findings and those of Ainley (1977) may be ascribed to several factors. Ainley originally studied only nesting assemblages of seabirds, but included non-breeding species in a later analysis (Ainley \& Boekelheide 1983). Incorporation of non-breeding species did not alter his eventual findings and conclusions about foraging strategies, however. The seabird assemblage off the coast of the southeastern USA differs from assemblages in the eastern Pacific Ocean in that very few species breed locally. Of those that do (i.e. Pelecanus occidentalis, Larus atricilla, Sterna maxima, S. sandvicensis, and $S$. antillarum), most generally breed outside of the immediate study area to the north or south. In essence we were studying a seabird assemblage made up almost entirely of nonbreeders. Distributions of birds were unlikely to be due to the presence or availability of nesting islands, thereby offering a better comparison for the influence of water clarity on marine habitat selection.

We examined foraging tactics over a relatively short turbidity gradient, about $150 \mathrm{~km}$. Ainley's study encompassed the entire eastern Pacific Ocean covering thousands of kilometers. Differences in the spatial scales of the studies may have produced the disparate results, but if generalities for seabird foraging tactics and water clarity are real, they should have applied at least as well at the shorter space scales we used.

Categorization of seabird behavior into a single foraging tactic may be inappropriate, and this may be a major reason that these predators do not appear to be as affected by water clarity as are other aquatic animals (cf. Confer et al. 1978, Gardner 1981). Some seabirds use 2 or more methods of prey capture (Ainley \& Boekelheide 1983) and it would be instructive to investigate whether the allocation of tactics within individual birds or species changes over turbidity gradients. Theoretically, some compensation for reductions in prey detectability across turbidity gradients may be accomplished by increasing search height (Eriksson 1985). If seabirds forage at greater heights over turbid water, then they may be able to initially detect prey over larger surface areas, offsetting the loss of detectability in less transparent water.
Changes in seabird foraging strategies across environmental gradients are well-documented (Murphy 1936, Ashmole 1971, Ainley 1977, Brown 1980, Ainley \& Boekelheide 1983, Hunt \& Schneider 1987), but different reasons for these patterns have been postulated. Ashmole (1971) suggested that the nature of the food sources' or prey type was closely related to the method by which that prey is obtained. Ainley (1977) rejected that proposal, emphasizing water clarity, water temperature, primary productivity, and other indirect oceanographic factors as better explanatory variables. Brown (in Hunt \& Schneider 1987) offered an altemative hypothesis. He suggested that the absence of surface divers in transparent, tropical waters is because this mode of foraging requires structural adaptations that also demand fast-flapping flight, an energetically expensive method of foraging given the patchy distribution of prey in tropical seas.

Plunge diving is a subset of all aerial foraging strategies which also include dipping, aerial pursuit and piracy, and skimming (Ashmole 1971). We speculate that plunge diving is a secondary consequence of morphological adaptations for efficient gliding or soaring flight. These adaptations have evolved in seabirds foraging over tropical and generally clear waters where productivity is low and prey are widely dispersed. Such adaptations preclude pursuit-diving foraging tactics (Brown 1980).

A different approach for studying seabird foraging strategies, prey abundance, and detectability would be to examine the relative amount of aerial ability within species groupings across marine environmental gradients. Two quantitative measurements for aerial ability that may be used include wing loadings and aspect ratios (Pennycuick 1972, 1982, Warham 1977). We would thus predict that the fraction of avian numbers and biomass with low wing loadings and high aspect ratios is directly proportional to water clarity, and inversely proportional to biomass standing stocks. Before acceptance as a generality, however, comparisons of aerial adaptations to environmental gradients should be made over several spatial scales in different marine systems. In addition, rather than focusing on plunge diving alone, all types of aerial foraging strategies should be included in such analyses.

Acknowledgements. We thank S. S. Bishop. J. A. Yoder, and $K$. Lecke for access to data on water clarity in the South Atlantsc Bight. The captains and crews of the research vessels 'Blue Fin', 'Bulldog', 'Cape Hatteras', 'Chapman', 'Delaware I', 'Oregon I', and 'Oregon II' were most helpful. Financial support was received from the University of Georgia Department of Zoology, the Burleigh-Stoddard Fund, and NSF grants OCE81-10707 to L. R. Pomeroy and OCE81-17761 to G.-A. Paffenhöfer. Logistical support was provided by the University of Georgia Marine Extension Service, Skidaway 
Appendix 1. Positions, temperatures, water chemistry, Secchi depth, and water color at 21 stations sampled for water transparency on RV 'Oregon II' Cruise 152

\begin{tabular}{|c|c|c|c|c|c|c|c|}
\hline Station & $\begin{array}{l}\text { Date } \\
(1985)\end{array}$ & Position & $\begin{array}{c}\text { Temperature } \\
\left({ }^{\circ} \mathrm{C}\right)\end{array}$ & $\begin{array}{c}\text { Salinity } \\
(\% 0)\end{array}$ & $\begin{array}{l}\text { Dissolved } \mathrm{O}_{2} \\
\quad(\mathrm{ppm})\end{array}$ & $\begin{array}{l}\text { Secchi depth } \\
(\mathrm{m})\end{array}$ & $\begin{array}{l}\text { Water color } \\
\text { (Forel-Ule) }\end{array}$ \\
\hline IS-1 & 3 May & $\begin{array}{l}31^{\circ} 40^{\prime} \mathrm{N} \\
80^{\circ} 59^{\prime} \mathrm{W}\end{array}$ & 22.3 & 33.4 & 7.1 & 3.0 & 10 \\
\hline IS- 2 & 3 May & $\begin{array}{l}32^{\circ} 01^{\prime} \mathrm{N} \\
80^{\circ} 44^{\prime} \mathrm{W}\end{array}$ & 21.7 & 33.6 & 7.3 & 4.0 & 4 \\
\hline IS -3 & 6 May & $\begin{array}{l}32^{\circ} 15^{\prime} \mathrm{N} \\
80^{\circ} 17^{\prime} \mathrm{W}\end{array}$ & 21.0 & 33.3 & 7.1 & 9.0 & 5 \\
\hline IS -4 & 6 May & $\begin{array}{l}32^{\circ} 26^{\prime} \mathrm{N} \\
80^{\circ} 15^{\prime} \mathrm{W}\end{array}$ & 21.8 & 34.2 & 7.9 & 10.0 & 4 \\
\hline IS -5 & 7 May & $\begin{array}{l}32^{\circ} 39^{\prime} \mathrm{N} \\
79^{\circ} 34^{\prime} \mathrm{W}\end{array}$ & 21.6 & 35.0 & 7.5 & 10.0 & 3 \\
\hline IS-6 & 7 May & $\begin{array}{l}32^{\circ} 56^{\prime} \mathrm{N} \\
79^{\circ} 12^{\prime} \mathrm{W}\end{array}$ & 21.0 & 34.2 & 7.8 & 8.0 & 4 \\
\hline IS-7 & 9 May & $\begin{array}{l}33^{\circ} 35^{\prime} \mathrm{N} \\
78^{\circ} 49^{\prime} \mathrm{W}\end{array}$ & 21.6 & 36.0 & 7.3 & 10.0 & 5 \\
\hline IS- 8 & 9 May & $\begin{array}{l}33^{\circ} 40^{\prime} \mathrm{N} \\
78^{\circ} 29^{\prime} \mathrm{W}\end{array}$ & 20.0 & 35.0 & 7.6 & 13.0 & 4 \\
\hline IS -9 & 10 May & $\begin{array}{l}33^{\circ} 47^{\prime} \mathrm{N} \\
77^{\circ} 53^{\prime} \mathrm{W}\end{array}$ & 20.5 & 35.5 & 6.9 & 8.5 & 5 \\
\hline MS-1 & 3 May & $\begin{array}{l}31^{\circ} 42^{\prime} \mathrm{N} \\
80^{\circ} 29^{\prime} \mathrm{W}\end{array}$ & 20.9 & 35.4 & 7.2 & 13.0 & 3 \\
\hline MS-2 & 6 May & $\begin{array}{l}32^{\circ} 03^{\prime} \mathrm{N} \\
80^{\circ} 03^{\prime} \mathrm{W}\end{array}$ & 21.3 & 36.3 & 7.4 & 20.0 & 1 \\
\hline MS-3 & 6 May & $\begin{array}{l}32^{\circ} 13^{\prime} \mathrm{N} \\
79^{\circ} 31^{\prime} \mathrm{W}\end{array}$ & 21.4 & 36.3 & 7.7 & 15.0 & 3 \\
\hline MS-4 & 7 May & $\begin{array}{l}32^{\circ} 30^{\prime} \mathrm{N} \\
79^{\circ} 10^{\prime} \mathrm{W}\end{array}$ & 21.0 & 35.0 & 7.2 & 12.0 & 3 \\
\hline MS-5 & 8 May & $\begin{array}{l}32^{\circ} 57^{\prime} \mathrm{N} \\
78^{\circ} 42^{\prime} \mathrm{W}\end{array}$ & 21.0 & 33.0 & 7.3 & 10.0 & 3 \\
\hline MS-6 & 9 May & $\begin{array}{l}33^{\circ} 22^{\prime} \mathrm{N} \\
78^{\circ} 33^{\prime} \mathrm{W}\end{array}$ & 21.0 & 34.2 & 7.6 & 9.0 & 5 \\
\hline MS-7 & $10 \mathrm{May}$ & $\begin{array}{l}33^{\circ} 35^{\prime} \mathrm{N} \\
77^{\circ} 32^{\prime} \mathrm{W}\end{array}$ & 21.9 & 36.3 & 6.4 & 14.5 & 3 \\
\hline MS-8 & $10 \mathrm{May}$ & $\begin{array}{l}33^{\circ} 43^{\prime} \mathrm{N} \\
77^{\circ} 37^{\prime} \mathrm{W}\end{array}$ & 20.3 & 34.2 & 6.7 & 7.0 & 6 \\
\hline OS-1 & 10 May & $\begin{array}{l}33^{\circ} 14^{\prime} \mathrm{N} \\
77^{\circ} 37^{\prime} \mathrm{W}\end{array}$ & 24.9 & 35.0 & 6.3 & 15.0 & 3 \\
\hline US-1 & 4 May & $\begin{array}{l}31^{\circ} 20^{\prime} \mathrm{N} \\
79^{\circ} 17^{\prime} \mathrm{W}\end{array}$ & 25.2 & 34.7 & 6.7 & 9.0 & 3 \\
\hline US-2 & 4 May & $\begin{array}{l}31^{\circ} 13^{\prime} \mathrm{N} \\
79^{\circ} 06^{\prime} \mathrm{W}\end{array}$ & 25.2 & 36.4 & 6.6 & 19.0 & 1 \\
\hline
\end{tabular}


Appendix 2. Nomenclature (AOU 1983) and principal foraging tactics of seabirds on the southeastern USA continental shelf and slope

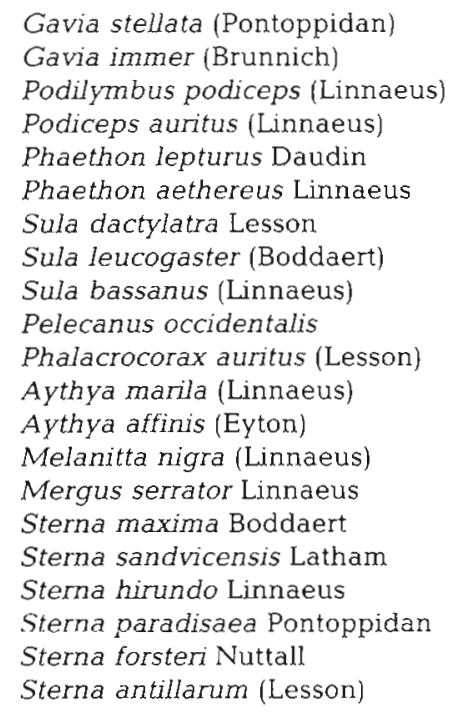

Red-throated loon
Common loon
Pied-billed grebe
Horned grebe
White-tailed tropicbird
Red-billed tropicbird
Masked booby
Brown booby
Northern gannet
Brown pelican
Double-crested cormorant
Greater scaup
Lesser scaup
Black scoter
Red-breasted merganser
Royal tern
Sandwich tern
Common tern
Arctic tern
Forster's tern
Least tern
Pursuit diving
Pursuit diving
Pursuit diving
Pursuit diving
Plunge diving
Plunge diving
Plunge diving
Plunge diving
Plunge diving
Plunge diving
Pursuit diving
Pursuit diving
Pursuit diving
Pursuit diving
Pursuit diving
Plunge diving
Plunge diving
Plunge diving
Plunge diving
Plunge diving
Plunge diving

Institute of Oceanography, South Carolina Wildlife and Marine Resources Department, and the National Oceanic and Atmospheric Administration/National Marine Fisheries Service. S. MacIntosh drafted the figures.

\section{LITERATURE CITED}

Ainley, D. G. (1977). Feeding methods in seabirds: a comparison of polar and tropical nesting communities in the eastern Pacific Ocean. In: Llano, G. A. (ed.) Adaptations within Antarctic ecosystems. Smithsonian Inst., Washington, D.C., p. 669-685

Ainley, D. G., Boekelheide, R. J. (1983). An ecological comparison of oceanic seabird communities of the South Pacific Ocean. Stud. Avian Biol. 8: 2-23

Andersson, G., Berggren, H., Cronberg, G., Gelin, C. (1978). Effects of planktivorous and benthivorous fish on organisms and water chemistry in eutrophic lakes. Hydrobiologia 59: 9-15

Aoll (1983). Checklist of North American birds, 6th edn. American Ornithologists' Union, Washington, D.C.

Ashmole, N. P. (1971). Sea bird ecology and the marine environment. In: Farner, D. S., King, J. R. (eds.) Avian biology, Vol. 1. Academic Press, New York, p. 224-286

Atkinson, L. P., Lee, T N., Blanton, J. O., Chandler, W S. (1983). Climatology of the southeastem United States continental shelf waters. J. geophys. Res. 88: 4705-4718

Blanton, J O., Atkinson, L. P. (1983). Transport and fate of river discharge on the continental shelf of the southeastem United States. J. geophys. Res. 88: 4730-4738

Bowman, M. J., Iverson, R. L. (1977). Estuarine and plume fronts. In: Bowman, M. J., Esaias, W. E. (eds.) Oceanic fronts in coastal processes. Springer Verlag, New York, p. $88-104$

Brooks, J. L., Dodson, S. I. (1965). Predation, body size and composition of the plankton. Science 150:28-35

Brown, R. G. B. (1980). Seabirds as marine animals. In: Burger,
J., Olla, B., Winn, H. E. (eds.) Behavior of marine animals, Vol. 4. Plenum Press, New York, p. 1-39

Confer, J. L., Howwick, G. L., Corzette, M. H., Kramer, S. L., Fitzgibbon, S., Landesburg, R. (1978). Visual predation by planktivores. Oikos 31:27-37

Eriksson, M. O. G. (1985). Prey detectability for fish-eating birds in relation to fish density and water transparency. Ornis Scand. 16: 1-7

Galbraith, M. J. (1967). Size selective predation on Daphnia by rainbow trout and yellow perch. Trans. Am. Fish. Soc. 96: $1-10$

Gardner, M. B. (1981). Mechanisms of size selectivity by planktivorous fish: a test of a hypothesis. Ecology 62 : $571-578$

Geddes, M. C. (1984). Seasonal studies on the zooplankton community of Lake Alexandrina, River Murray, South Australia, and the role of turbidity in determining zooplankton community structure. Aust. J. mar. Freshwat. Res. 35: 417-426

Haney, J. C. (1986). Pelagic seabird ecology and its relationship to environmental heterogeneity in the South Atlantic Bight. Ph. D. dissertation, Univ. of Georgia, Athens

Henrikson, L., Nyman, H. G., Oscarson, H. G., Stenson, J. A. E. (1980). Trophic changes without changes in the external loading. Hydrobiologia 68: 257-263

Hunt, G. L., Jr, Schneider, D. C. (1987). Scale dependent processes in the physical and biological environment of marine birds. In: Croxall, J. D. (ed.) Seabird feeding. Cambridge Univ. Press, London

Lee, T N., Atkinson, L. P. (1983). Low-frequency current and temperature variability from Gulf Stream frontal eddies and atmospheric forcing along the southeast U. S. outer continental shelf. J. geophys. Res. 88: 4541-456?

Lynch, M. (1979). Predation, competition, and zooplankton community structure: an experimental study. Limnol. Oceanogr. 24: 253-272

McCabe, G. D., O'Brien, W. J. (1983). The effects of suspended silt on the feeding and reproduction of Daphnia. Am. Midl. Nat. 110: 324-337 
Murphy, R. C. (1936). Oceanic birds of South America. Am. Mus. Nat. Hist., New York

Olson, D. B., Brown, O. B., Emmerson, S. R. (1983). Gulf Stream frontal statistics from Florida Straits to Cape Hatteras derived from satellite and historical data. J. geophys. Res. 88: 4569-4577

Patalas, K., Salki, A. (1984). Effects of impoundment and diversion on the crustacean plankton of Southern Indian Lake. Can. J. Fish. aquat. Sci. 41: 613-637

Pennycuick, C. J. (1972). Animal flight. Edward Arnold Ltd, London

Pennycuick, C. J. (1982). The flight of petrels and albatrosses (Procellariformes), observed in South Georgia and its vicinity. Phil. Trans. R. Soc. B300: 75-106

Preisendorfer, R. W. (1986). Secchi disk science: visual optics of natural waters. Limnol. Oceanogr. 31: 909-926

Salt, G. W., Villard, D. E. (1971). The hunting behavior and success of Forster's Tern. Ecology 52: 989-999

Sverdrup, H. V., Johnson, M. W., Fleming, R. H. (1942). The oceans: their physics, chemistry, and general biology. Prentice-Hall, New York

Timms, B. V. (1970). Chermical and zooplankton studies of lentic habitats in north-eastern New South Wales. Aust. J. mar. Freshwat. Res. 21: 11-33

Vinyard, G. L., O'Brien, W. J. (1976). Effects of light and turbidity on the reactive distance of bluegill (Lepomis machrochirus). J. Fish. Res. Bd Can. 33: 2845-2849

Warham, J. (1977). Wing loadings, wing shapes, and flight capabilities of Procellariformes. N. Z. J. Zool. 4: 73-83

Yoder, J. A., Atkinson, L. P., Bishop, S. S., Hofmann, E. E., Lee, T. N. (1983). Effect of upwelling on phytoplankton productivity on the outer southeastern U.S. continental shelf. Cont. Shelf Res. 1: 385-404

Zettler, E. R., Carter, J. C. H. (1986). Zooplankton community and species responses to a natural turbidity gradient in Lake Temiskaming, Ontario-Quebec. Can. J. Fish. Aquat. Sci. 43: 665-673

This article was submitted to the editor; it was accepted for printing on May 11, 1988 